\title{
Global construction materials database and stock analysis of residential buildings between 1970-2050
}

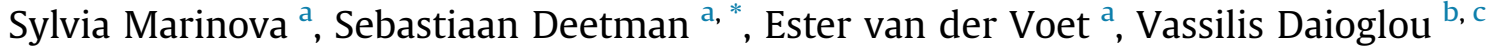 \\ ${ }^{a}$ CML - Institute of Environmental Sciences, Leiden University, Einsteinweg 2, 2333 CC, Leiden, the Netherlands \\ ${ }^{\mathrm{b}}$ PBL Netherlands Environmental Assessment Agency, PO Box 30314, 2500 GH, The Hague, the Netherlands \\ ${ }^{\mathrm{c}}$ Copernicus Institute of Sustainable Development, Utrecht University, Princetonlaan 8a, 3584 CB, Utrecht, the Netherlands
}

\section{A R T I C L E I N F O}

\section{Article history:}

Received 30 January 2019

Received in revised form 25 October 2019

Accepted 2 November 2019

Available online 7 November 2019

Handling editor: Yutao Wang

\section{Keywords:}

Material intensity

Residential buildings

Construction materials stock

Urban mining

Floor space

Scenario assessment

\begin{abstract}
A B S T R A C T
Huge material stocks are embedded in the residential built environment. These materials have the potential to be a source of secondary materials, an important consideration for the transition towards a circular economy. Consistent information about such stocks, especially at the global level, is missing. This article attempts to fill part of that gap by compiling a material intensities database for different types of buildings and applying that data in the context of a scenario analysis, linked to the SSP scenarios as implemented in the global climate model IMAGE. The database is created on a global scale, dividing the world into 26 regions in compliance with IMAGE. The potential use of the database was tested and served as input for modelling the housing and material stock of residential buildings for the period 1970-2050, according to specifications made for the SSP2 scenario. Six construction materials in four different dwelling types in urban and rural areas are included. The material flows related to those stocks are estimated and analysed in a companion paper (also exploring commercial buildings) by Deetman et al. (2019). The results suggest a significant increase in the material stock in housing towards 2050, particularly in urban areas. The results reflect specific patterns in the material contents across the different building types. China presently dominates developments in the global level building stock. The SSP2 projections show a stock saturation towards 2050 for China. In other regions, such as India and South East Asia, stock growth is presently just taking off and can be expected to become dominant for global developments after 2050. The database is created to be used as input for resource and climate policymaking as well as assessment of environmental impact related to residential buildings and assessment of possibilities for urban mining. In the future, we hope to extend it as new data on materials in the built environment become available.
\end{abstract}

(c) 2019 Elsevier Ltd. All rights reserved.

\section{Introduction}

The demand for primary materials has increased significantly during the last decades, driven by industrialisation and economic development. The demand for raw materials is forecasted to continue growing with the increase in global population and affluence $(O E C D, 2013)$, resulting in a growing in-use stock of materials. An important share of these materials is related to residential buildings. The residential building sector accounts for $30-50 \%$ of the material consumption, forming a massive material stock which increased during the past years and is expected to

\footnotetext{
* Corresponding author.

E-mail addresses: sylvia.marrinova@gmail.com (S. Marinova), deetman@cml. leidenuniv.nl (S. Deetman).
}

expand further (Steger and Bleischwitz, 2011). Demographic changes and increased Gross Domestic Product (GDP) are expected to lead to a growth in the demand for floor area and construction materials respectively (OECD, 2013), both per capita and in an absolute sense. The built environment is associated with considerable environmental impacts related to the construction and operation of buildings, ranging from the extraction and transformation of resources to the increased energy demand of the in-use buildings (Augiseau and Barles, 2017). At the same time, it represents a huge urban mine of valuable raw materials for secondary resource providers. As yet, there is little insight into these stocks. However, knowledge of these stocks and their dynamics is essential information for a transition towards the circular economy (Müller, 2006; Krausmann et al., 2017).

Individual estimations of stocks and flows of building materials 
on a national and regional level have been performed and described in various studies. However, so far, there is little harmonisation: each of these studies has its focus, uses its data and makes its own methodological choices. Material Flow Analysis (MFA) is the methodology widely used to quantify the materials flows and stocks in the built environment. The two main approaches of material stock assessment can be described as bottom-up and topdown (Auping et al., 2014; Urge-Vorsatz et al., 2012). The topdown approach calculates stocks at the aggregate level, as the result of net-additions-to-stock of a material over a period of time. The bottom-up approach divides the stock into categories of products or applications and estimates the stock by characterising each of its components with a material intensity ratio (e.g. $\left.\mathrm{kg} / \mathrm{m}^{2}\right)$.

Over the past years, efforts have been made to explore the dynamics of the stock (Müller, 2006; Olaya et al., 2017; Hashimoto et al., 2007). For instance, Müller (2006) applied stock dynamics modelling to forecast the resource demand simultaneously with the related waste generation. Hu et al. (2010) (Hu et al., 2010) used Müller's dynamic stock model as a basis for the development of an MFA model which represents the changes in the residential buildings floor area in use in China between 1900 and 2100. A number of studies developed this approach further and explored the material composition of the stock while taking into consideration the generation of construction and demolition waste (Hashimoto et al., 2007; Hu et al., 2010; Reyna and Chester, 2015; Aksoezen et al., 2016), as well as the spatial distribution of the stock (Heeren and Hellweg, 2018; Tanikawa and Hashimoto, 2009; Kleemann et al., 2016; Koutamanis et al., 2018).

Recognising the importance of the environmental implications of material demand, researchers assessed the relationship between the material stock and negative impacts related to the built environment such as energy consumption and greenhouse gas emissions. The most recent studies employ a Life Cycle Assessment (LCA) approach and take into account material and energy flows in addition to emissions related to the life cycle of the building itself (Stephan et al., 2012; Yang et al., 2018; Nemry et al., 2010).

In recent years, a small but growing number of studies has been conducted with the purpose to record, store and analyse information on the material content of the built environment. For example, Gontia et al. (2018) (Gontia et al., 2018) developed a material intensities database of residential buildings in Sweden. The study explores 46 buildings and separates them according to their building type, construction type and construction period. In addition, Kleemann at al. (2016) (Kleemann et al., 2016) developed a material content database in order to investigate the building stock in Vienna, Austria. Another study compiling a material database along with the investigation the total material stock and flows resulted from demolition waste is Miatto et al. (2019) (Miatto et al., 2019), recording detailed information of material intensities of buildings in one city (Padua, Italy). Besides, Heeren at al. (2019) (Heeren and Fishman, 2019) compiled a material intensities database on a global scale by extracting information from 33 studies and recording approximately 300 data points from those studies.

Studies like these recognise the importance of the material stock but address it in individual case studies at various scale levels. On the global scale, the available literature associated with material stocks in the built environment is limited, and lacking in detail. To address this gap, this article aims to summarise the existing knowledge on the residential building stock composition, to integrate it into a global level material content database, and to test the usability of the database by applying it in a global material stocks model for residential buildings. To facilitate using these data for scenario assessments, we do this in relation to the IMAGE (Integrated Model to Assess the Global Environment) Integrated Assessment modelling suite as used by PBL (Netherlands
Environmental Assessment Agency) for the assessment of global level climate change scenarios (Stehfest et al., 2014a; Doelman et al., 2018; van Vuuren et al., 2017; O’Neill et al., 2017).

This article has the following objectives:

- Review of existing studies using different approaches to identify the material content in residential buildings.

- Compile a database of materials used in the construction of residential buildings at the global level in accordance with the IMAGE regions.

- Test the applicability of the database in a scenario context by modelling the past, present and future material stock in residential buildings based on IMAGE data and the materials database, using a bottom-up approach.

This paper focuses on stocks of materials in residential buildings. In a companion paper (Deetman et al., 2019) (Deetman et al., 2019), we add two pieces of research:

- A stock assessment of materials in various types of commercial buildings

- An assessment of inflows and outflows related to both residential and commercial buildings: the stock of building materials, and waste streams related to demolition.

\section{Methodology and data}

\subsection{The building stock model}

In order to assess the practical applicability of the database, we apply a stock model which aims to determine the in-use stock of construction materials used in the built environment and makes estimations of their future stock. In this paper, we focus on the inuse stock of residential buildings. The starting point for the stock estimations is the total Useful Floor Area (UFA) specified for 26 world regions, as projected by the IMAGE model and described by Daioglou et al. (2012) (Daioglou et al., 2012). Section 2.2 describes this in more detail. The UFA is translated into material stock for the period between 1970 and 2050 by using material intensities per square meter UFA. Similar to Müller's model (Müller, 2006) the main drivers in the system are population and lifestyle in terms of UFA per capita.

The building stock model distinguishes between urban (including suburbs) and rural areas, as well as different types of residential buildings: detached houses, row houses, apartment buildings and high-rise buildings (Van Beers and Graedel, 2003; Stephan, 2013; Carre and Crossin, 2015). The additional variables that feed the model are the distribution of the population over the different dwelling types, the total UFA per building type for the 26 regions, and the material quantity per building type expressed in terms of $\mathrm{kg} / \mathrm{m}^{2}$ UFA.

As mentioned above, the urban/rural distinction is made in the IMAGE-TIMER projections, while the distribution over the different dwelling types is calculated based on national statistics (Residential Energy Consumption Survey (RECS) - Energy Information Administration, 2019; Australian GovernmentAustralian Bureau of Statistics, 2019; Eurostat, 2019). The material intensity is based on the existing literature, reviewed and documented in a material intensities database. The different calculations steps and data sources are discussed in the next section and are illustrated in Fig. 1.

\subsection{The IMAGE model and the SSP scenarios}

The IMAGE integrated assessment model (IAM) assesses the 


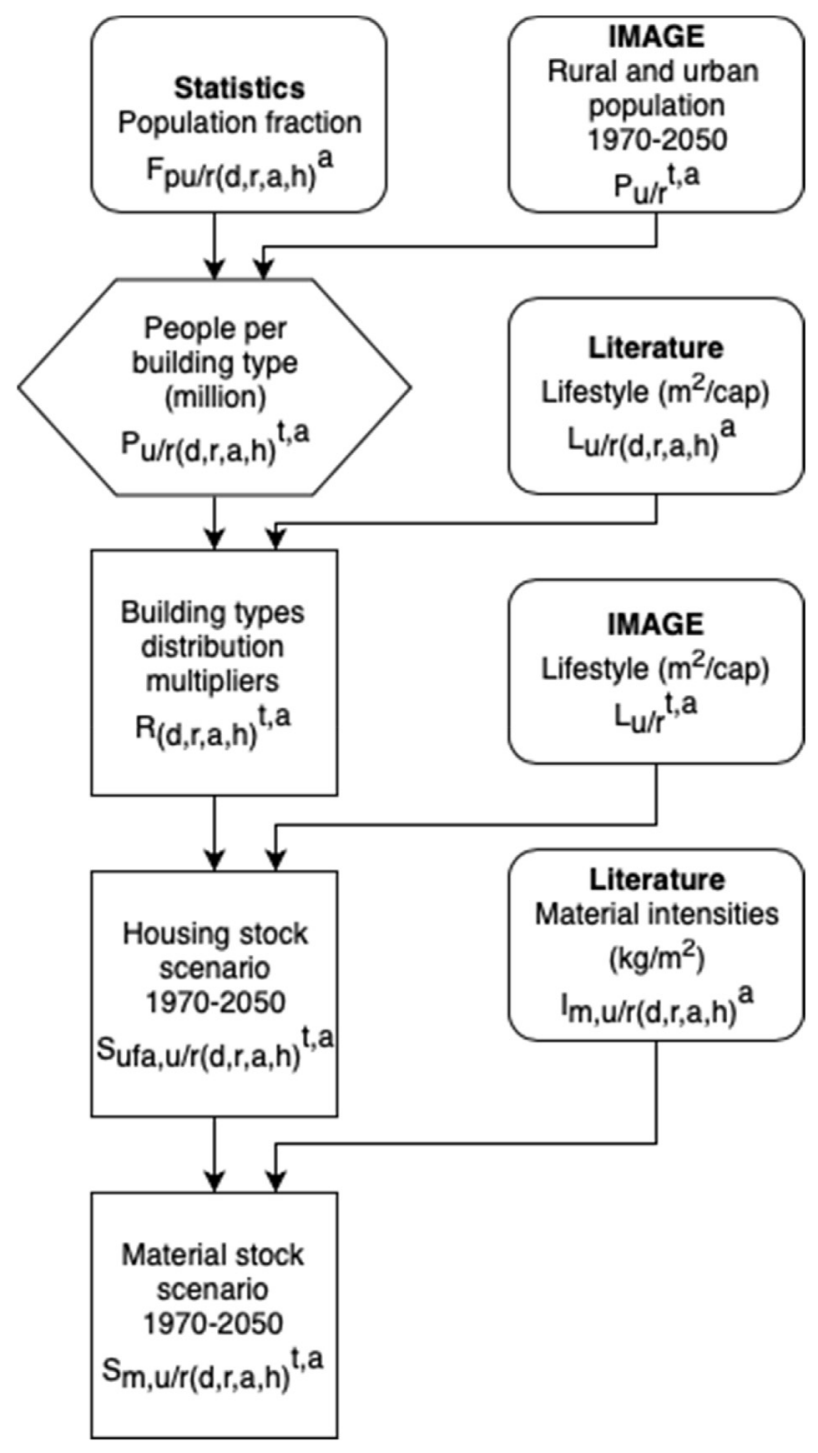

Fig. 1. Outline of the material stock analysis model. The rectangles represent the variables or drivers, the squares illustrate the stock and the hexagon is a calculation step. The data sources are written in bold.

interactions between human development and natural systems. The model identifies the impact of energy consumption, land, water and other natural resources use on the natural environment and explores policy options concerning sustainable development, climate change and land use. IMAGE generate scenarios of socioeconomic developments based on a set of drivers (Stehfest et al., $2014 b)$. The model operates on a global scale, dividing the world into 26 regions. IMAGE has various sub-models on agriculture, land use, energy systems etc. One of these sub-models is the IMAGE Energy Regional model or TIMER. TIMER simulates the composition and dynamics of the energy system and projects its potential future trajectories and greenhouse gas emissions. The main variables used as input for the model are population and sectoral activity (e.g. GDP, Private Consumption) as they are identified as the most important drivers of energy demand (Van Vuuren et al., 2007). The model developed in this paper makes a similar assumption and regards population and lifestyle (in this case expressed as Useful Floor Area (UFA) per capita) as a driving force for material demand.

IMAGE, together with similar IAMs, is used to project the narrative of the Shared Socio-Economic Pathways (SSP) scenarios
(Riahi et al., 2017). The SSP scenarios describe five different trajectories of socio-economic development of the world and are used as a basis for assessing climate change and sustainable development at the global level (van Vuuren et al., 2017). Each trajectory has a baseline variant which includes future developments without considering extra climate mitigation policies. Each also has variants with different levels of ambition for reaching climate policy targets. All of the SSP scenarios can be linked to an estimation of the building and material stock. For the purpose of the current study, we consider only the SSP2 baseline scenario which assumes moderate population growth, economic and technological development and contains no specific efforts towards sustainable development. The SSP2 scenario is regarded as the "middle of the road" SSP scenarios, as it projects present trends and developments into the future (KC and Lutz, 2017).

We use the IMAGE framework, and especially the TIMER model, to generate driving force data for stocks of materials in residential buildings. The TIMER model has detailed representation of the development of long term and global residential energy demand across urban and rural households, calibrated to historical data. The residential energy demand is linked to changes in demographic and economic development, as well as lifestyle parameters. These, in turn, affect "intermediate indicators" also generated by TIMER, including household sizes and residential floorspace (Daioglou et al., 2012).

Using the IMAGE framework has the advantage of enabling a link to globally recognised scenarios. Reciprocally, adding our model of the built environment to TIMER will enable to assess development scenarios on their consequences for resource requirements as well as environmental impacts in one modelling endeavour.

\subsection{Data, variables and calculations}

Fig. 1 illustrates the calculation procedures as well as data sources. A full representation can be found in the supplementary information of the companion paper by Deetman et al. The model involves four processes, depicted by hexagon and squares in the figure. The starting point for the material stock analysis model is IMAGE/TIMER. TIMER provides population numbers for all 26 regions over the period 1970-2050, divided into urban and rural population. TIMER also provides UFA per capita for the 26 regions and the period 1970-2050. By multiplying those, we obtain total UFA per region over time, divided into rural and urban population.

This information needs to be detailed further by allocating the thus obtained UFA data over the four different housing types (detached houses, row houses, apartment buildings and high-rise buildings). TIMER does not deliver that information. We derived multipliers for this allocation process based on population and housing statistics on the one hand, and our literature database on material intensities of buildings on the other hand. Statistics tell us the number of the population living in the four different types of dwellings $\left(\mathrm{P}_{\mathrm{u} / \mathrm{r}}\right)$, which we recalculate into the share of the population $\left(\mathrm{Fp}_{\mathrm{u} / \mathrm{r}}\right)$. The literature database provides, for the buildings investigated, square meters of UFA per house of each type, which we recalculate into $\mathrm{m}^{2} \mathrm{UFA} / \mathrm{cap}$ and which we assume is an indicator for lifestyle (L) which is building type-specific (d,r,a,h). The UFA/cap varies across dwelling types and is different for rural and urban areas. These we use as weighting factors to obtain multipliers or allocation factors for distributing the total UFA over the different dwelling types (R).

The stock or the UFA $\left(\mathrm{S}_{\mathrm{ufa}}\right)$ is then obtained by multiplying the total UFA which we obtained from IMAGE-TIMER by these allocation factors $R$. This is done per region and per year over the 1970-2050 period, and for urban and rural areas. Finally, the 
housing stock in terms of square meters is multiplied with the material intensity data in terms of $\mathrm{kg} / \mathrm{m}^{2}$ of the different materials, to determine the materials stocks $\left(\mathrm{S}_{\mathrm{m}}\right)$, also per region and per year, and for six different materials.

\subsubsection{Population}

The population data - historical numbers and projections until 2050 for each for the 26 regions - are extracted from TIMER, based on the SSP2 scenario, as mentioned earlier. The description of the regional classification can be found in Appendix A (Figure A.1). The historical data are based on United Nations' data and the projections on the assumptions made by the International Institute for Applied Systems Analysis (IIASA) (KC and Lutz, 2017). The future population projections are based on various assumptions related to economic, educational, policy and technical development of the globe and the individual regions, and are shaped by demographic rates and migration flows (van Vuuren et al., 2017; Dellink et al., 2017).

\subsubsection{Distribution of population over the different dwelling types}

Based on the difference in the construction materials, construction practices and even climate conditions, the residential buildings can significantly vary. To increase the reliability of the database and facilitate its usage, we chose to break down the stock of residential buildings into types. Four different building types were identified for the purpose of the study: detached houses, semi-detached/row houses, apartment buildings and high-rise buildings. The distinguishing of the dwelling types is based on a study conducted by Kumar et al. (2015) (Kumar et al., 2015), which recognises the most common types of buildings in Canada and is supported by data from national housing statistics. We made the distinction between apartments and high-rise buildings based on the number of floors: apartment buildings are defined as comprised of separated units within a building with a maximum of four storeys. This assumption is made based on the difference in the construction of buildings above four storeys and the need for reinforcement (steel) which leads to changes in the material composition (Engineering students' guide to multi-storey buildings, 2019). We exclude the informal dwelling types typical for many of the developing countries due to lack of data on the material quantities in these buildings. We acknowledge their importance and we hope more building types will be incorporated in the database in the future.

Furthermore, we acknowledge that not only the materials but also the average house size, in terms of square meters per capita, is different for each building type (i.e. detached houses tend to be more spacious than apartments) and even between urban and rural areas. We attempt to account for this by applying a weighted disaggregation of the stock based on regionally specified average per capita floor space, as found in reviewed literature discussed in Section 1. For further information on the disaggregation, please refer to the Supplementary Information (SI).

Finally, another important note is that we consider that the population is not equally distributed throughout the four different housing types. In order to calculate the percentage of people living in different types of dwellings, data on the distribution of the population by dwelling type is collected from statistical sources. This type of information is not available at the global level. We used statistical information from Europe, North America, Australia and Japan, respectively from Eurostat, EIA's Office of Energy Consumption and Efficiency Statistics (Residential Energy Consumption Survey (RECS) - Energy Information Administration, 2019), the Australian Bureau of Statistics (Australian GovernmentAustralian Bureau of Statistics, 2019) and Statistics of Japan (tat Japan and 2015 Populat, 2015). The data can be found in
Table 1.

The statistical information presented in Table 1 originates from a selection of developed countries. For most regions, such data were not available. For these regions, we applied global averages which we calculated from the available information. The representativeness thus may be questioned. In the future, as more data become available, the quality of these assumptions can be improved.

\subsubsection{Lifestyle}

The floor area per capita is one of the United Nation's indicators to trace the progress towards meeting the goals of the Global Strategy for Shelter (UN-HABITAT, 2013). We, therefore, use the floor area (UFA) per capita as an indicator of lifestyle. An increase in this indicator implies an improvement in the living conditions of the population.

The per capita floor area (L) provided by the IMAGE-TIMER model increases towards 2050 for all regions. The minimum values found in the set are for urban India: $7 \mathrm{~m}^{2}$ per capita for the present (average of 2000-2015), increasing to $16 \mathrm{~m}^{2}$ per capita towards the end of the modelling period (2035-2050). On the other end of the scale we found rural United States, currently showing an average of $57 \mathrm{~m}^{2}$ per capita, which increases to $63 \mathrm{~m}^{2}$ / cap towards mid-century.

Both the population share and the average per capita floor space for different building types (four building types in urban and rural areas) are static assumptions. This is most probably not realistic; however, we have no grounds to make different assumptions. In the scenario calculations, changes in this distribution originate only from urbanisation: an increased share of urban areas.

\subsubsection{Materials intensity database}

No official statistical datasets are available for material quantities in buildings. There is, however, a modest body of studies focused on the material contents in residential buildings (Gontia et al., 2018; Miatto et al., 2019; Heeren and Fishman, 2019). We used these studies to create our database, by translating this information into material intensity indicators $\left(\mathrm{I}_{\mathrm{m}}\right)$ : the material content per square meter UFA. We included six materials in our database: concrete, steel, aluminium, copper, wood and glass.

In order to create the database, a list of publications was reviewed and a total of 56 studies was selected from this list to be included. The studies selected for the database were chosen based on their purpose, spatial and time scale, materials studied and the level of detail. The literature research process is described below.

First, we reviewed publications focused on compiling material intensities data for buildings. For the purpose of the current paper, we used two studies containing material intensities databases (Gontia et al., 2018; Heeren and Fishman, 2019). One of the studies has a national scope as it includes a database of material contents in residential buildings in Sweden (Gontia et al., 2018). The other presents a database at the global level (Heeren and Fishman, 2019).

Second, we explored MFA studies including flows and stocks of residential buildings and construction materials. The studies investigating stocks were preferred given that the current paper focuses on stocks and does not look into material flows. Eleven studies from this category were included in the database (Hashimoto et al., 2007; Reyna and Chester, 2015; Tanikawa and Hashimoto, 2009; Gontia et al., 2018; Miatto et al., 2019; Van Beers and Graedel, 2003; Stephan and Athanassiadis, 2018; Condeixa et al., 2017; Johnstone, 2001; Mesta et al., 2018; Huang et al., 2013). Some of them assess materials in the existing in-use building stock at a local scale (Reyna and Chester, 2015; Miatto et al., 2019; Condeixa et al., 2017; Johnstone, 2001). Other papers have a more general character as they focus on the material stock in entire countries (Hashimoto et al., 2007; Van Beers and Graedel, 
Table 1

Population share $\left(\mathrm{P}_{\mathrm{d}}\right)$ by building type according to various statistical offices.

\begin{tabular}{|c|c|c|c|c|c|c|}
\hline Region & Area & $\begin{array}{l}\text { Detached } \\
\text { Houses }\end{array}$ & $\begin{array}{l}\text { Semi-detached/Row } \\
\text { Houses }\end{array}$ & $\begin{array}{l}\text { Apartment } \\
\text { Buildings }\end{array}$ & $\begin{array}{l}\text { High-rise } \\
\text { Buildings }\end{array}$ & Comments \\
\hline North & Urban & $52.7 \%$ & $5.7 \%$ & $7.1 \%$ & $13.8 \%$ & Based on $<$ EIA (Residential Energy Consumption Survey (RECS) - Energy \\
\hline America & Rural & $19.8 \%$ & $0.3 \%$ & $0.5 \%$ & $0.1 \%$ & Information Administration, 2019)> \\
\hline Western & Urban & $15.9 \%$ & $22.3 \%$ & $17.3 \%$ & $20.0 \%$ & Based on <Eurostat (Eurostat, 2019) $>$ \\
\hline Europe & Rural & $13.6 \%$ & $6.1 \%$ & $3.6 \%$ & $1.3 \%$ & \\
\hline Eastern & Urban & $19.4 \%$ & $3.8 \%$ & $5.2 \%$ & $29.8 \%$ & Based on $<$ Eurostat (Eurostat, 2019) $>$ \\
\hline Europe & Rural & $34.2 \%$ & $2.4 \%$ & $2.1 \%$ & $3.1 \%$ & \\
\hline \multirow[t]{2}{*}{ Australia } & Urban & $21.9 \%$ & $40.3 \%$ & $16.0 \%$ & $5.9 \%$ & Based on $<$ ABS (Australian GovernmentAustralian Bureau of Statistics, 2019) $>$ \\
\hline & Rural & $14.5 \%$ & $0.8 \%$ & $0.7 \%$ & $0.0 \%$ & \\
\hline \multirow[t]{2}{*}{ Japan } & Urban & $37.1 \%$ & $1.2 \%$ & $17.7 \%$ & $12.9 \%$ & Based on <EStat Japan (tat Japan and 2015 Populat, 2015)> \\
\hline & Rural & $27.5 \%$ & $0.5 \%$ & $2.8 \%$ & $0.3 \%$ & \\
\hline \multirow[t]{2}{*}{ Average } & Urban & $29.4 \%$ & $14.7 \%$ & $12.6 \%$ & $16.5 \%$ & Applied to other regions \\
\hline & Rural & $21.9 \%$ & $2.0 \%$ & $2.0 \%$ & $1.0 \%$ & \\
\hline
\end{tabular}

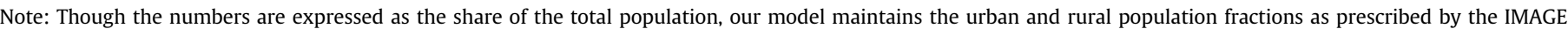
elaboration of the SSP2 scenario, so only the relative fraction within the urban or the rural population is used to disaggregate stock across the four building types.

2003). The assessment of the spatial distribution of the material stock using Global Information System (GIS) is the purpose of four of these studies (Tanikawa and Hashimoto, 2009; Kleemann et al., 2016; Van Beers and Graedel, 2003; Mesta et al., 2018). Estimating the material in- and outflows by using data on the material demand together with construction and demolition activities is the aim of several other papers (Stephan and Athanassiadis, 2018; Huang et al., 2013).

Third, studies dealing with the LCA of residential buildings were reviewed. We identified various studies conducted with different purposes in the broad context of energy efficiency, efficient use of materials and the possibilities for their recovery (Reyna and Chester, 2015; Yang et al., 2018; Stephan, 2013; Carre and Crossin, 2015; Kumar et al., 2015; Johnstone, 2001; Evangelista et al., 2018; Oyarzo and Peuportier, 2014; Ortiz-Rodríguez et al., 2010; Henry et al., 2014; Ezema and Olotuah, 2015; Nemry and Uihlein, 2008; Asif et al., 2005; Cuéllar-Franca and Azapagic, 2012; Buyle et al., 2015; Pajchrowski et al., 2014; Atmaca and Atmaca, 2015; Stephan and Stephan, 2014; Asif et al., 2017; El Hanandeh, 2015; Pinky Devi and Palaniappan, 2014; Bansal et al., 2014; Sharma and Marwaha, 2015; Ramesh et al., 2012; Shukla et al., 2009; Lee et al., 2017; Jeong et al., 2012; Lee et al., 2015; Chen et al., 2001; Li et al., 2016; Su and Zhang, 2016; Jia Wen et al., 2015; Abd Rashid et al., 2017; Utama and Gheewala, 2009; Utama and Gheewala, 2008; Suzuki et al., 1995; Rauf and Crawford, 2015; Carre, 2011; Aye et al., 2011; Fay et al., 2000; Bhochhibhoya et al., 2017; Zhang et al., 2014; Reza et al., 2014). Whenever they included data on the material composition of buildings, we used them in our database. We found that the most abundant sources are the LCA studies estimating the environmental impact of residential buildings (Kumar et al., 2015; Evangelista et al., 2018; Oyarzo and Peuportier, 2014; OrtizRodríguez et al., 2010; Cuéllar-Franca and Azapagic, 2012; Jeong et al., 2012) and investigating the performance of the residential buildings in terms of energy as well the possibilities for energy optimisation using alternative materials (Kumar et al., 2015; Pajchrowski et al., 2014; Lee et al., 2017; Zhang et al., 2014; Blanchard and Reppe, 1998; Mosteiro-Romero et al., 2014).

Next to those studies, we included various publications specifying material intensities of particular houses. These publications were often useful since they are very specific and contain field data. The downside of these papers is that they lack representativeness. If necessary, we recalculated the data from these studies into kilograms of specific materials per square meter of UFA. The calculation steps can be found in the database in the Supplementary data. A full list with all of the papers can be found in the database as well (Appendix B).

We used those studies to compile a database containing material intensities $\left(\mathrm{kg} / \mathrm{m}^{2}\right)$ per building type and region. For 9 out of the 26 regions, the review did not yield any relevant studies. When no information was available for a specific region, material or housing type, we applied a global mean value based on the other regions with available data, as shown in Table 2 in the Results section.

\section{Results}

In this section, we present the main results. All numbers and further details can be found in the Supplementary data of this paper, and of Deetman et al. (2019) (Deetman et al., 2019).

\subsection{The database}

The data collected during the study resulted in a database containing a summary of the reviewed literature. The database contains information on the material content of the six materials for the four building types in $\mathrm{kg}$ per $\mathrm{m}^{2}$ UFA. In addition, the database contains the floor areas of each building type that we calculated from the TIMER info and the distribution over the different types of buildings. The results of the calculations are presented in the SI.

\subsubsection{Material content}

Table 2 depicts the values for the mean material contents across the four different dwelling types for six different construction materials at present. When calculating the material quantities, we did not distinguish between rural and urban areas assuming that the material intensities in the residential buildings in both areas are similar. More detailed information related to the different regions is presented in Appendix A (Table A.2).

Steel, concrete and wood appear to be the materials most commonly included in studies on material intensities. For aluminium, copper and glass the number of data points is much lower.

The material intensities show high variability. This could be due to the variability in architecture and construction. However, some materials have a more standard use than others. Concrete, wood and steel are used for the structure of the house. Copper is used for wiring and piping, and sometimes ornamental. Glass is used for windows and sometimes, in high rise buildings, for surfaces of buildings. Aluminium is used for window frames and also, widely varying, as an ornamental material. We can, therefore, expect the data for aluminium and glass to show the highest variability.

The studies taken into consideration in this paper show that concrete is the main material in terms of quantity used in the 
Table 2

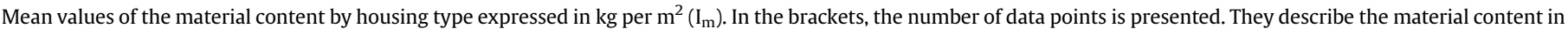

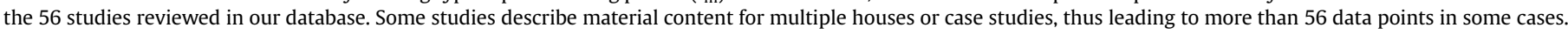

\begin{tabular}{|c|c|c|c|c|c|c|}
\hline & Steel & Concrete & Wood & Copper & Aluminium & Glass \\
\hline Detached Houses & $35.63(87)$ & $846.33(104)$ & $53.07(121)$ & $1.73(13)$ & $3.56(19)$ & $2.68(43)$ \\
\hline Row Houses & $32.89(8)$ & $1208.13(11)$ & $34.97(10)$ & $0.01(4)$ & $0.23(1)$ & $1.07(1)$ \\
\hline Apartment Buildings & $97.36(53)$ & $955.92(84)$ & $37.17(82)$ & $0.31(22)$ & $1.94(17)$ & $6.35(33)$ \\
\hline High-rise Buildings & $116.98(30)$ & $910.21(56)$ & $54.48(36)$ & $0.01(1)$ & $2.20(6)$ & $4.42(25)$ \\
\hline
\end{tabular}

Notes: For region-specific details, please see the SI.

construction of houses (Ortiz-Rodríguez et al., 2010; Asif et al., 2005; Cuéllar-Franca and Azapagic, 2012; Abd Rashid et al., 2017). Concrete intensity is high in all housing types (often $>1000 \mathrm{~kg} / \mathrm{m}^{2}$ ). The values in Table 2 show that steel is mainly used in apartments and high-rise buildings. Intensities in detached and row houses are much lower. Apartments and high-rise buildings use steel as a structural material, either in columns and beams as such, or as a part of reinforced concrete (Mesta et al., 2018; Zhang et al., 2014). The results for wood show a higher intensity for detached houses. We assume that these results are mostly due to the fact that the single-family houses presented in the database are mostly woodbased constructions (Oyarzo and Peuportier, 2014; Pajchrowski et al., 2014). For copper, as well, detached and semi-detached houses show the highest density. This may be explained by the higher density in plumbing and wiring for these more spread-out housing types. Finally, the glass content in detached houses and high-rise buildings comes out higher compared to the quantities in the remaining dwelling types.

Table 2 also shows the number of data points (between brackets) from the 56 studies in our database, that are used to calculate the mean of the material content and the material stock. It is important to note that the data points do not correspond to the number of studies addressing certain material. They reflect the data on individual houses available in the database.

\subsection{Stock}

Based on the information from the previous section compiled in the database and the data delivered from the IMAGE-TIMER model the development of the housing and material stock $\left(S_{u f a}\right.$ and $\left.S_{m}\right)$ was calculated.

\subsubsection{Housing stock}

Fig. 2 presents the housing stock development in square meters for the IMAGE regions according to TIMER for the period 1970-2050, distributed over the different housing types. The 26 regions are grouped in 3 different categories related to their pattern of development: fast-developing regions which include South American countries, Africa and Asia, steadily developed regions comprised of North-America, Europe, Oceania, Russia and the Middle East, and finally China and Japan. China and Japan are grouped based on the similarity of the projected development of their total housing stocks until 2050: these countries are the only ones with a stock that declines towards the end of that period.

Fig. 2a represents the urban areas and indicates consistent growth throughout the modelled period. According to the projections, the growth is particularly rapid in the fast-developing regions. More surprising is the steady growth in the housing stock in developed regions. This phenomenon originates from the projections made by the SSP2 scenario assuming that the urban population will still increase, as will the UFA/cap, although slowly (van Vuuren et al., 2017). The fast growth of the in-use floor space in the fast-developing regions indicated the improvement in the living standards in these lower-income countries (Wang et al.,

\section{7).}

Fig. 2b, illustrating the rural areas, shows different patterns. As one would expect the square meters for detached houses dominate. It is interesting to highlight that the housing stock of the steadily developed countries as well as of the China and Japan group is expected to decrease in the period after 2030. This phenomenon can be explained with the growing urbanisation and the trends related to the relocation of the population towards urban areas, including the suburbia (van Vuuren et al., 2017).

\subsubsection{Material stock}

By combining the housing stock in terms of floor space calculated for the period between 1970 and 2050 and the information on the material contents delivered from the database we were able to calculate the material stock. This section presents a few of the results that can be obtained from the material stock time series. Fig. 3 presents the global material stock distributed between urban and rural areas in 2018 and 2050. Concrete dominates the total stock of materials, representing over $90 \%$ of the total weight. Furthermore, the model results show that the stock of materials in residential buildings is expected to almost double until 2050, and will be located increasingly in urban areas. In rural areas, the stock of materials is not expected to grow so much, and in some cases may even decline somewhat. Only for copper, the scenario results show an increase in rural areas. This result suggests an interpretation related to the structure of the housing stock: detached houses have a higher copper intensity than the high-rise and apartment buildings. It may also be a consequence of limited data availability. The data points for copper are scarce and the results based on a limited set of studies. In general, the coverage of the database leads to different reliability of the results for different regions and different materials, and the results should, therefore, be used with caution. We elaborate on this issue in the discussion section.

Fig. 4 illustrates the development of the steel stock as one material which plays an important role in the process of urbanisation. The information could be relevant for urban mining and usage as secondary material (Stephan and Athanassiadis, 2017; Schebek et al., 2017). The results show the rapid development of China's housing stock since 1980 , and especially since 2000 , and the concurrent great increase in the steel stock in residential buildings. After 2035 a saturation of the stock is visible and near mid-century, the growth of the steel stock in Chinese residential buildings is expected to cease. Still, model results indicate that a significant part of the global steel in-use stock can be found in China in 2050. China is a country with a huge population showing rapid development. According to the SSP2 scenario, roughly 35\% of the housing stock in square meters will be located in China in 2050, and the share is even higher for the steel-intensive high rise and apartment buildings. None of the other 26 areas shows a pattern like China. All have much slower growth, although for India and Africa an acceleration can be detected near the end of the model period. The stock development of rest of the studied materials is shown in Figure A2 in the Supplementary information.

Fig. 5 shows the development of the stock of five materials in 


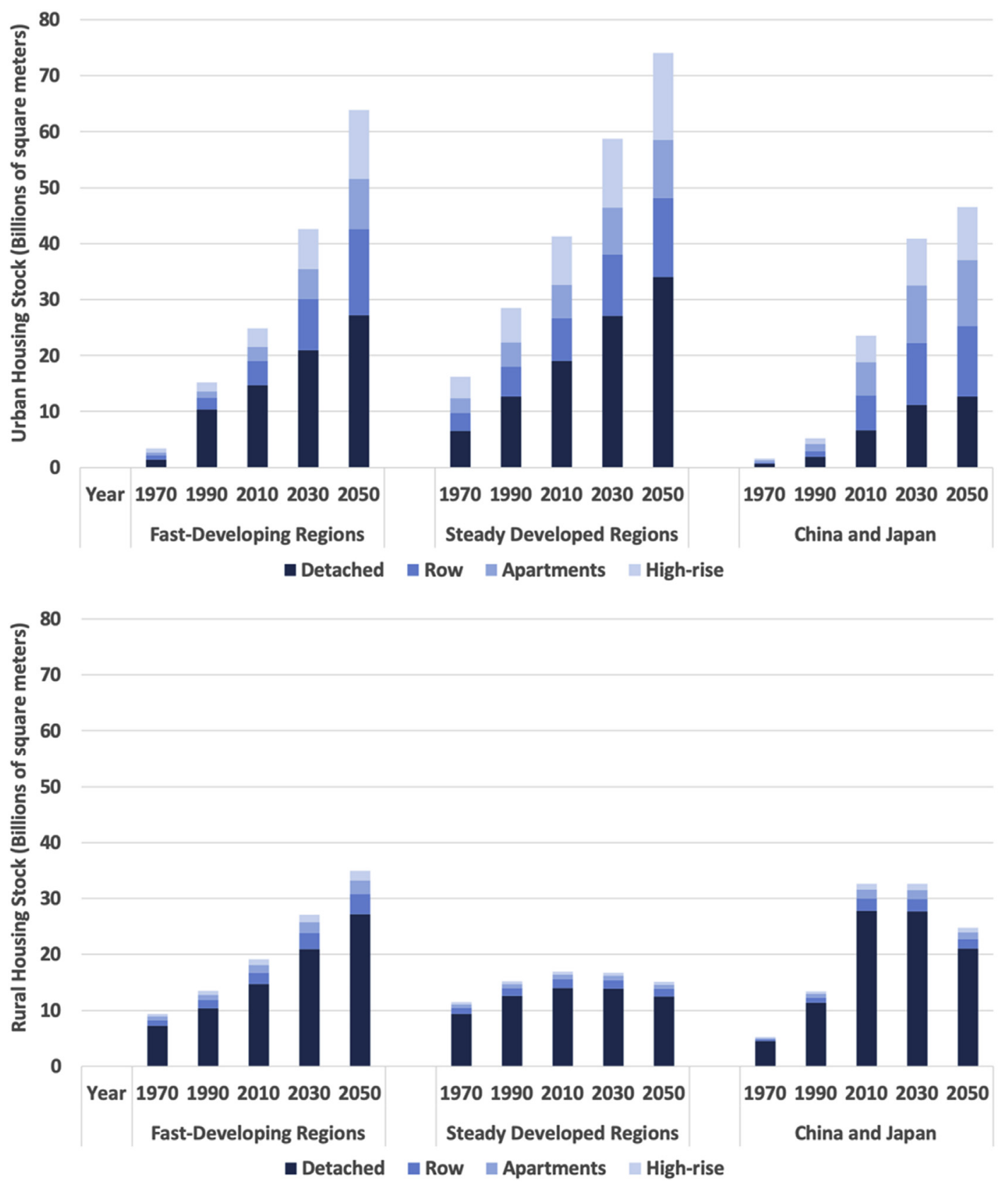

a)

b)

Fig. 2. Urban and Rural housing stock represented in square meters across four dwelling types and three regional categorisations. The graph on the top represents the urban areas while the bottom one depicts the rural areas. The countries representing the fast-developing regions are all South American countries, Africa and Asia, except China and Japan which are placed in a separate category, to show their distinct stock dynamics. The steadily developed regions consist of North-America, Europe, Australia, New Zeeland, Russia and the Middle East. The graph on the top illustrates the housing stock in urban areas whilst the bottom figure shows the stock in the rural areas.

China (left) and India (right). The results show a significant difference in the stock behaviour across the two countries. The graph depicting China illustrates the same trends as in Fig. 4 - rapid growth from 2000 onward, and saturation or even decline of the stock for all materials near 2050. The graph representing India shows a rapid growth for all materials, which is not expected to slow down before mid-century. Please note the different scales of the $y$-axes of both figures.

\subsection{Data uncertainty and sensitivity analysis}

Fig. 6 shows the distribution of the material intensity data by illustrating the 20th and 80th percentiles as well as the mean and the median value for each building type and material. If a study has more data points describing the same building type and material, we use the mean of the values within that study.

We chose to present the data distribution in percentiles. The percentiles allow us to display the number below which $20 \%$ and $80 \%$ of the values can be found. In Fig. $6 a$, a higher range of the data set can be observed. The distance between the minimum and the maximum value in relation to the mean is large for each of the building types, which shows the diversity in the data and available construction methods. On the contrary, in Fig. $6 \mathrm{~b}$ the steel in detached and row houses depicts a smaller range of the data in the available studies.

The material content per building type, the useful floor area per 

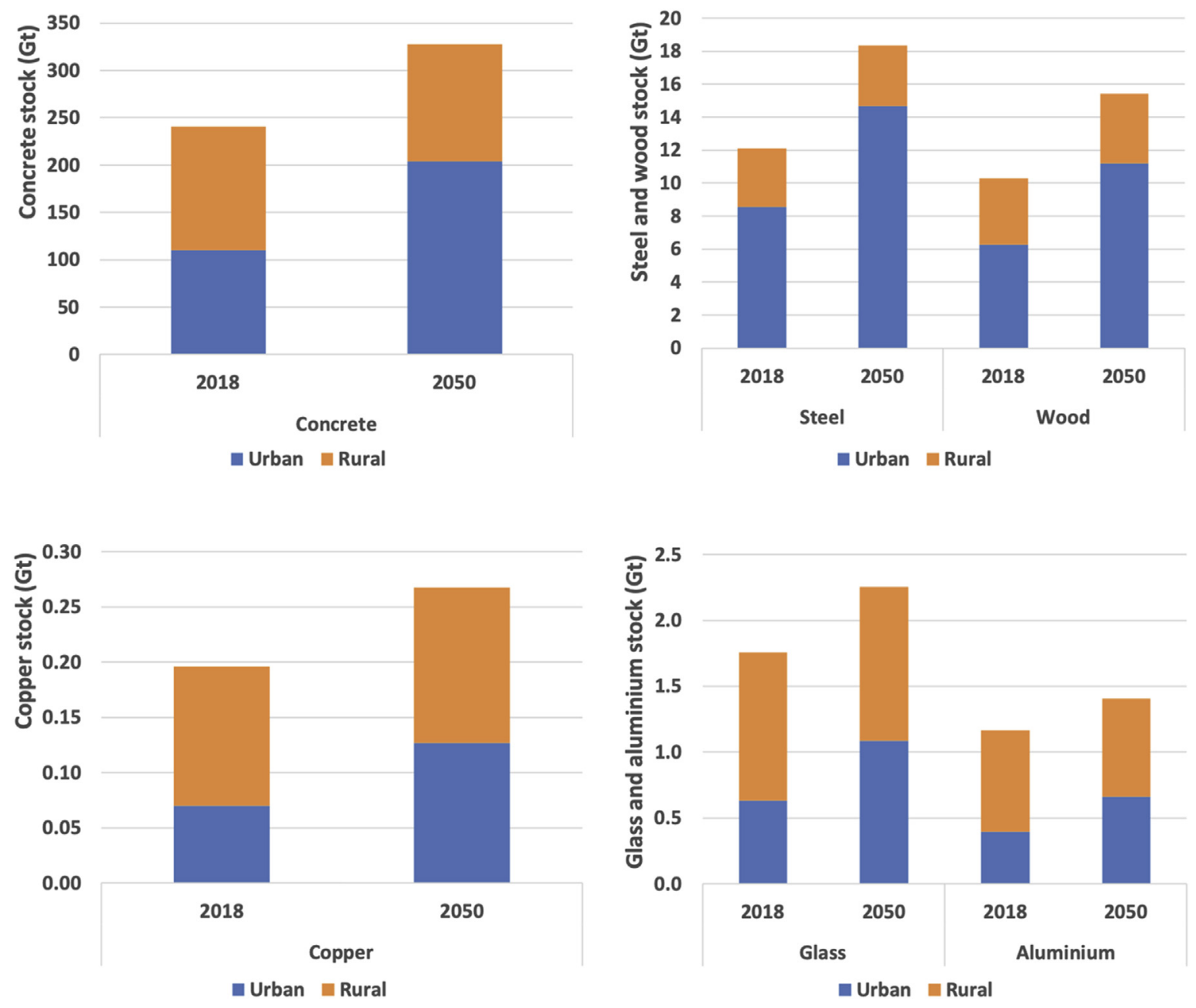

Fig. 3. Material stock in urban and rural areas on a global level. Current values and predictions for 2050, for concrete, steel, wood, copper, glass and aluminium.

capita, and the population are the main drivers in the model described in the previous section. There is a certain degree of uncertainty related to the development of all three of these variables, therefore it is important to estimate the impact of these drivers on the model outcomes (Hong et al., 2016). The UFA/cap and the population forecasts are generated by the IMAGE model. Since these data are also used in other assessments, notably in the scenarios for climate change, we will not include those in our sensitivity analysis. Instead, we focus on the sensitivity of the outcomes for different estimates of the material content per square meter of UFA.

Fig. 6 shows the influence of changes in the material intensity parameter on the stock model. We show the 20 percentile, 80 percentile and the median material content values in addition to the mean value which we have been applying as a standard. The 20 and 80 percentile values provide a reasonable bandwidth for our results - based on the present state of knowledge, the "true" value will probably be in that range. The median could be used as an alternative for the mean value. Results are presented in the Supplementary information (Table A.4 and Figure A.3). Median, 20th percentile and 80th percentile refer to the database at a global level.

The 20th and 80th percentile values show a wide range, with a factor 4 difference between lowest and highest values. A remarkable finding is that both mean and median values are closer to the 20th percentile values than they are to the 80th percentile value.
That would suggest that the high material content values from the database represent more a-typical buildings.

The sensitivity analysis shows a difference between the mean and median values: for most of the materials, the median values are lower than the mean. This, too, suggests some outliers on the high side of the spectrum. An argument could be made to use the median values instead of the mean. We decided not to do that - in a field where there is still so little information, we do not know whether the very high values are exceptional (to be excluded) or just part of the normal range (and therefore to be included). More research will hopefully clarify this point.

In all, we conclude that the database on material contents for doing such stock assessments is sufficient to arrive at order-ofmagnitude credible values, but still is limited and could benefit from further expansion of data and details regarding regional differentiation and differentiation over the housing types. This is a challenge for future database building, to be taken up by researchers, but also by architects, construction companies and demolishers.

\subsection{Material stock comparison with literature}

The values for the Chinese in-use steel stock show very high values in comparison with the rest of the world regions. To check the reasonability of our estimates, we compared our results with 


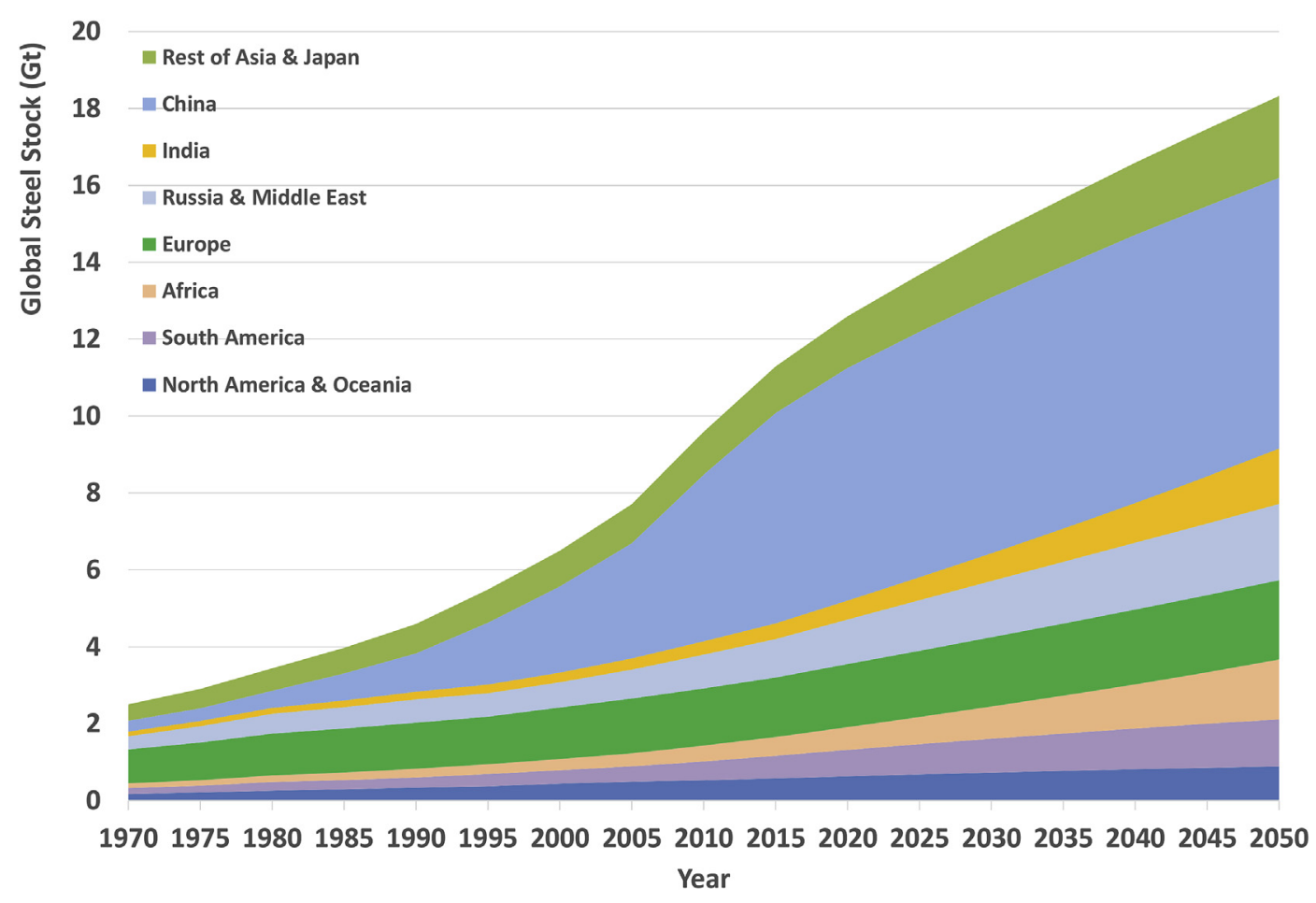

Fig. 4. Global stock of steel across ten regions for the period between 1970 and 2050.
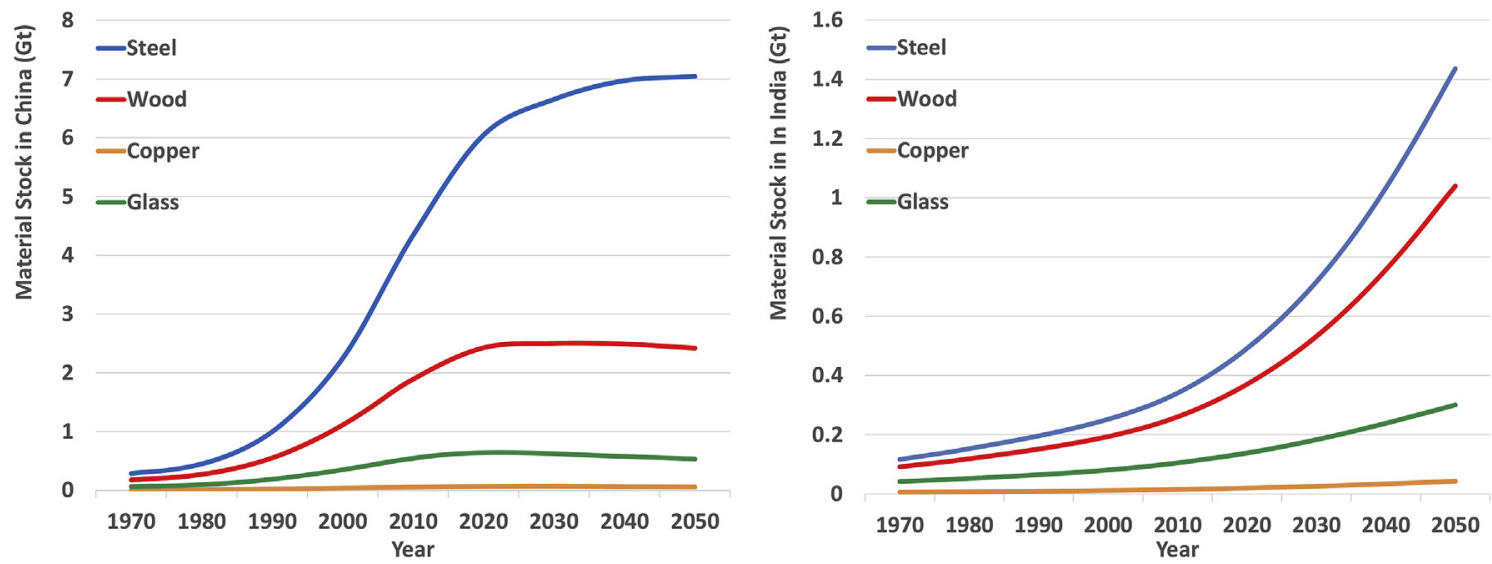

Fig. 5. Four materials in residential housing stock in China (left) and India (right).

previous steel stock estimations for China (Pauliuk et al., 2013a, 2013b; Hatayama et al., 2010). The results can be found in the Supplementary information (Section 5). We conclude from it that our estimates are, although not identical, still in the same order - if the difference would be relevant, our estimates appear to be on the low side.

\section{Discussion and conclusion}

In the above, we reviewed a collection of studies on material content of the residential built environment and, consequently, developed a database of the material intensities. We used this information together with the output of the IMAGE-TIMER model to generate data on the material stock of residential buildings at the global scale, for the period 1970-2050.

The database contains material content data per square meter of useful floor area of residential buildings for six materials, four housing types, and urban and rural areas, for the 26 IMAGE world regions. The database is still limited in the number of samples it includes. We have not been able to find data for all 26 IMAGE regions. However, we considered the database to be sufficient to calculate global mean values for each housing type. For those regions where we did not have sufficient data, we used these global means. In addition, we observed a large range in the material content data per housing type. One reason for that might be the large variety in types of buildings and materials within and between regions, that is insufficiently documented. Another reason might be the limited number of data points: as the number of studies is not that large, it may be that they do not combine to a representative sample.

We assessed the applicability of the material content database in a scenario context by generating stock developments over time of six major construction materials: concrete, wood, steel, aluminium, copper and glass using the SSP2 scenario as a 

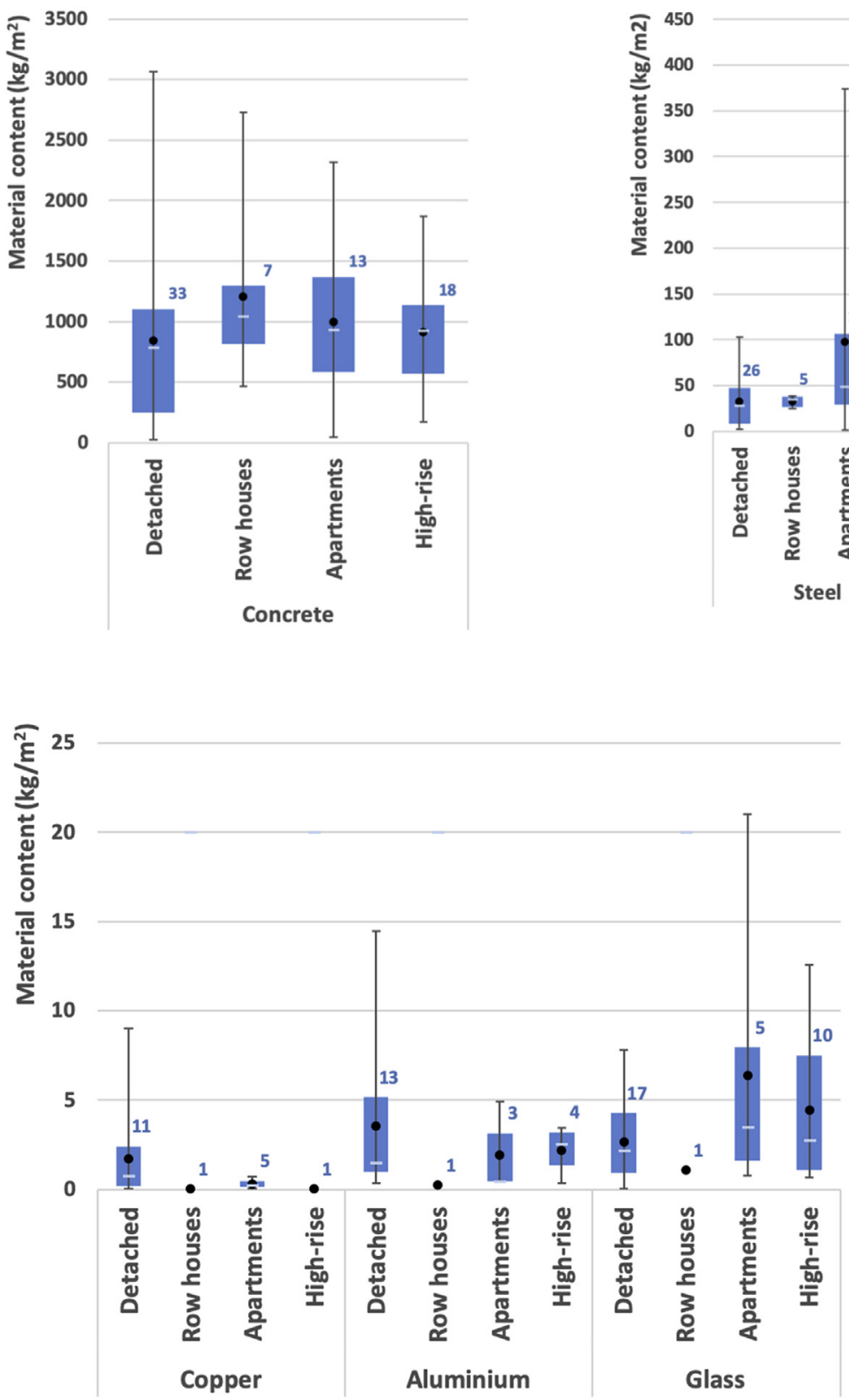

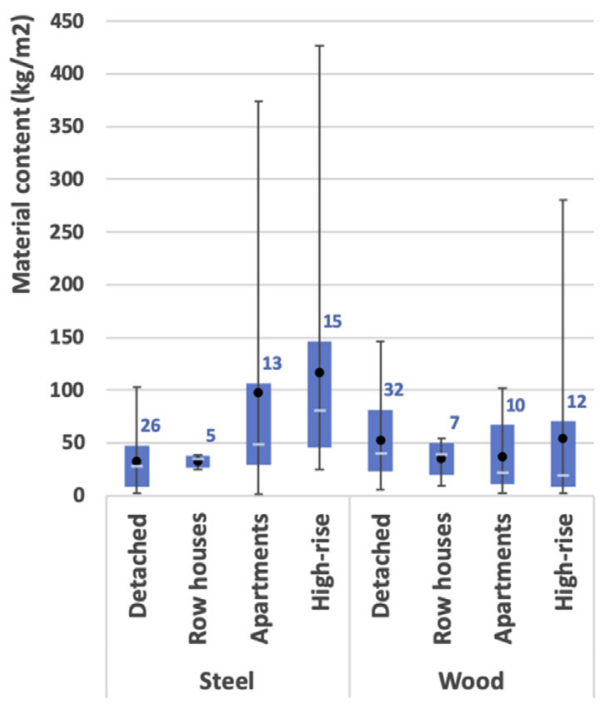

Legend

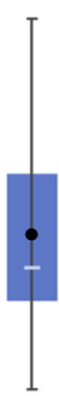

maximum

$80^{\text {th }}$ percentile

mean

median

$20^{\text {th }}$ percentile

minimum

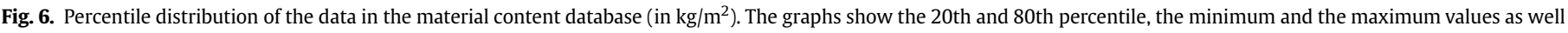

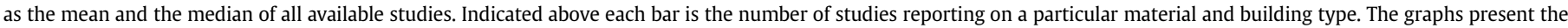
data distribution for concrete, for steel and wood and copper, aluminium and glass.

background. Changes (mostly increases) of the material stocks in residential buildings originate from three types of developments such as specified in IMAGE-TIMER:

(1) changes (mostly growth) in population leading to a changed (mostly larger) requirement for residential buildings

(2) changes (mostly increase) in affluence resulting in a changed (larger) UFA per capita over time, and

(3) urbanisation leading to a different distribution over the four types of residential buildings.

The database in our view represents a good first start of data collection required for scenario analysis. It is, nevertheless, far from complete and has strong limitations we hope can be overcome in time.
(1) There is a notable difference between the per capita UFA data from TIMER, and the UFA/cap emerging from the material intensity database. An explanation may be that the TIMER data include very small houses (including shacks and shanties), which are not represented in the studies investigating material content or material intensities of residential buildings. This implies that the material stocks as calculated by us could be an overestimation. Since we use the IMAGETIMER output for per capita floor space, this overestimation would not be the result of assuming too high values for the per capita floor area, but only of too high material intensity values.

(2) In general, developed countries are overrepresented in the material intensity database. This may not be a major problem for high rise buildings or apartment buildings, as these are 
not very different all over the world. For detached houses, which are generally much more traditional and differ greatly in their material composition throughout the world, the largest variations may be expected which may not be captured adequately in our database.

(3) The material intensities in the database are static. Although there is some evidence that material intensities in the built environment are subject to changes over time (Tanikawa and Hashimoto, 2009; Kleemann et al., 2016; Heeren and Fishman, 2019), we found insufficient data to enable including such changes in our model. Moreover, the data from IMAGE-TIMER refer to stocks and not flows, which means we have no information on the period in which the houses were actually built. We are thus presently unable to include developments in construction technologies and building design in our scenarios.

(4) The allocation of dwellings over the four housing types in urban and rural areas is static and relies on data for the present situation. Changes over time in this allocation have not been included in the scenario analysis.

All this implies that the uncertainties in the material intensities database are large. By making it available, we hope that results from future studies will be added, making it more suitable for answering further research questions related to resource scenario development and urban mining.

Despite these limitations, the results at the aggregate level presented above show that the database provides useful information and can be used in a scenario context. As a result of population increase, development and urbanisation, we see a considerable increase in the stock of residential buildings at a global level, with a concurrent increase in material stocks. For some materials, the growth of the stock appears to be larger than for others. The stock of steel, for example, is shown to rise by $50 \%$ by our calculations, while the stock of copper increases only with $25 \%$. The highest growth worldwide occurs in apartment buildings and high-rise buildings in urban areas, indicating urbanisation as the main reason for this difference.

Our results show a difference in stock behaviour between the different regions. In developed countries, the stock is generally slowly rising. China dominates global developments in the coming decades by its rapidly rising stock, but this growth is expected to level off towards 2050. In regions such as India, South East Asia and Africa, the stock is starting to rise now and according to our assumptions will continue to do so, probably long after 2050. These regions may become dominant for global developments after 2050.

Given the abovementioned uncertainties and data gaps, we have to conclude that the database we present is open for improvement. Nevertheless, we think it could already now be used to estimate future stock developments, and could be used as a starting point to assess options for reducing the environmental impacts as well as the possibilities for life span increase, recycling and using secondary materials in construction. These stock developments are a very important input for estimates about the flows of construction materials: the demand for construction materials, and the generation of demolition waste. How stock dynamics can influence flows is explored in a companion paper to this one (Deetman et al., 2019) (Deetman et al., 2019).

Such a stocks-and-flows database is very relevant input for global level assessments of policies on resource efficiency and circular economy. The size of the urban mine and what is coming out of it determines the potential for a circular economy. Having information on the different building types also allows for a better estimate of energy use in the built environment, which in turn is relevant to assess greenhouse gas emissions. Having information on the demand for materials enables assessing environmental impacts related to materials extraction and production, thereby providing a starting point for generating and assessing options to reduce these impacts.

So far, we have only included the SSP2 baseline scenario in our calculations. The same approach is applicable also for the other SSP scenarios. Especially when the projections on population and affluence differ, we expect the stocks of materials in the built environment to be different. The SSP scenarios may also provide a baseline to enrich with assumptions on resource efficiency or a circular economy, showing how policies in that direction may affect material demand. We hope to address these issues in future work. Having knowledge about the urban mine and the materials that will be available for secondary production allows assessing to what extent, and when, it will be possible to close cycles of those major construction materials. By the link to an IAM on climate change, it will thus become possible to assess the climate benefits (and drawbacks) of circular economy policies.

In conclusion, the results of the research show that, despite the rather limited information, we have been able to generate scenarios for the development of in-use stocks that make sense, and that can be used in a modelling environment that is relevant at a global level. The current study provides a foundation for the development of a more comprehensive material intensities database. By making the database available, we hope it will grow in future to allow for more detailed and more reliable assessments.

\section{Acknowledgements}

The authors would like to thank two anonymous reviewers for their very helpful comments, which contributed significantly to the clarity and quality of this paper.

\section{Appendix A. Supplementary data}

Supplementary data to this article can be found online at https://doi.org/10.1016/j.jclepro.2019.119146.

\section{References}

Abd Rashid, A., Idris, J., Yusoff, S., 2017. Environmental impact analysis on residential building in Malaysia using life cycle assessment. Sustainability 9, 1-15. https://doi.org/10.3390/su9030329.

Aksoezen, M., Hassler, U., Kohler, N., 2016. Reconstitution of the dynamics of an urban building stock. Build. Res. Inf. 45, 1-20. https://doi.org/10.1080/ 09613218.2016.1152040.

Asif, M.Ã., Muneer, T., Kelley, R., 2005. Life cycle assessment: a case study of a dwelling home in Scotland. Build. Environ. 42, 1391-1394. https://doi.org/ 10.1016/j.buildenv.2005.11.023.

Asif, M., Dehwah, A., Ashraf, F., Khan, H., Shaukat, M., Hassan, M., 2017. Life cycle assessment of a three-bedroom house in Saudi Arabia. Environments 4, 1-13. https://doi.org/10.3390/environments4030052.

Atmaca, A., Atmaca, N., 2015. Life cycle energy (LCEA) and carbon dioxide emissions (LCCO2A) assessment of two residential buildings in Gaziantep, Turkey. Energy Build. 102, 417-431. https://doi.org/10.1016/j.enbuild.2015.06.008.

Augiseau, V., Barles, S., 2017. Studying construction materials flows and stock: a review. Resour. Conserv. Recycl. 123, 153-164. https://doi.org/10.1016/ j.resconrec.2016.09.002.

Auping, W., Pruyt, E., Kwakkel, J., 2014. Dealing with multiple models in system dynamics: perspectives on the future of copper. Int. J. Syst. Dyn. Appl. 3, 17-35. https://doi.org/10.4018/ijsda.2014100102.

Australian Government, Australian Bureau of Statistics, 2019. http://www.abs.gov. au.

Aye, L., Ngo, T., Crawford, R.H., Gammampila, R., Mendis, P., 2011. Life cycle greenhouse gas emissions and energy analysis of prefabricated reusable building modules. Energy Build. 47, 159-168. https://doi.org/10.1016/ j.enbuild.2011.11.049.

Bansal, D., Singh, R., Sawhney, R.L., 2014. Effect of construction materials on embodied energy and cost of buildings - a case study of residential houses in India up to $60 \mathrm{~m} 2$ of plinth area. Energy Build. 69, 260-266. https://doi.org/ 10.1016/j.enbuild.2013.11.006.

Bhochhibhoya, S., Zanetti, M., Pierobon, F., Gatto, P., Maskey, R.K., Cavalli, R., 2017. 
The global warming potential of building materials: an application of life cycle analysis in Nepal. Mt. Res. Dev. 37, 47-55. https://doi.org/10.1659/MRD-JOURNAL-D-15-00043.1.

Blanchard, S., Reppe, P., 1998. Life cycle analysis of a residential home in Michigan. http://www.umich.edu/ cSS.

Buyle, M., Audenaert, A., Braet, J., Debacker, W., 2015. Towards a more sustainable building stock: optimizing a flemish dwelling using a life cycle approach. Buildings 5, 424-448. https://doi.org/10.3390/buildings5020424.

Carre, A., 2011. A Comparative Life Cycle Assessment of Alternative Constructions of a Typical. Australian House Design.

Carre, A., Crossin, E., 2015. A comparative life cycle assessment of two multi storey residential apartment buildings. www.fwpa.com.au.

Chen, T.Y., Burnett, J., Chau, C.K., 2001. Analysis of embodied energy use in the residential building of Hong Kong. Energy 26, 323-340. https://doi.org/10.1016/ S0360-5442(01)00006-8.

Condeixa, K., Haddad, A., Boer, D., 2017. Material flow analysis of the residential building stock at the city of Rio de Janeiro. J. Clean. Prod. 149, 1249-1267. https://doi.org/10.1016/j.jclepro.2017.02.080.

Cuéllar-Franca, R.M., Azapagic, A., 2012. Environmental impacts of the UK residential sector: life cycle assessment of houses. Build. Environ. 54, 86-99. https://doi.org/10.1016/j.buildenv.2012.02.005.

Daioglou, V., van Ruijven, B.J., van Vuuren, D.P., 2012. Model projections for household energy use in developing countries. Energy 37, 601-615. https:// doi.org/10.1016/j.energy.2011.10.044.

Deetman, S., Marinova, S., van der Voet, E., van Vuuren, D., Edelenbosch, O., Heijungs, R., 2019. Modelling Global Material Stocks and Flows for Residential and Commercial Buildings towards 2050.

Dellink, R., Chateau, J., Lanzi, E., Magné, B., 2017. Long-term economic growth projections in the shared socioeconomic pathways. Glob. Environ. Chang. 42 200-214. https://doi.org/10.1016/j.gloenvcha.2015.06.004.

Doelman, J.C., Stehfest, E., Tabeau, A., van Meijl, H., Lassaletta, L., Gernaat, D.E.H.J., Neumann-Hermans, K., Harmsen, M., Daioglou, V., Biemans, H., van der Sluis, S., van Vuuren, D.P., 2018. Exploring SSP land-use dynamics using the IMAGE model: regional and gridded scenarios of land-use change and land-based climate change mitigation. Glob. Environ. Chang. 48, 119-135. https://doi.org/ 10.1016/j.gloenvcha.2017.11.014.

El Hanandeh, A., 2015. Environmental assessment of popular single-family house construction alternatives in Jordan. Build. Environ. 92, 192-199. https://doi.org/ 10.1016/j.buildenv.2015.04.032.

Engineering students' guide to multi-storey buildings, 2019. https://www. steelconstruction.info/Engineering_students\%27_guide_to_multi-storey_ buildings\#Basic_principles_of_good_design.

Eurostat, 2019. https://ec.europa.eu/eurostat/data/database.

Evangelista, P.P.A., Kiperstok, A., Torres, E.A., Gonçalves, J.P., 2018. Environmental performance analysis of residential buildings in Brazil using life cycle assessment (LCA). Constr. Build. Mater. 169, 748-761. https://doi.org/10.1016/ j.conbuildmat.2018.02.045

Ezema, I.C., Olotuah, A.O., 2015. Estimating embodied energy in residential buildings in a Nigerian context. In: Article in International Journal of Applied Engineering Research, vol. 10, pp. 44140-44149. http://www.ripublication.com.

Fay, R., Treloar, G., Iyer-Raniga, U., 2000. Life-cycle energy analysis of buildings: a case study. Build. Res. Inf. 28, 31-41. https://doi.org/10.1080/096132100369073.

Gontia, P., Nägeli, C., Rosado, L., Kalmykova, Y., Österbring, M., 2018. Material-intensity database of residential buildings: a case-study of Sweden in the international context. Resour. Conserv. Recycl. 130, 228-239. https://doi.org/ 10.1016/j.resconrec.2017.11.022.

Hashimoto, S., Tanikawa, H., Moriguchi, Y., 2007. Where will large amounts of materials accumulated within the economy go? - a material flow analysis of construction minerals for Japan. Waste Manag. 27, 1725-1738. https://doi.org/ 10.1016/j.wasman.2006.10.009.

Hatayama, H., Daigo, I., Matsuno, Y., Adachi, Y., 2010. Outlook of the World Steel Cycle Based on the Stock and Flow Dynamics 44, 6457-6463. https://doi.org/ $10.1021 / \mathrm{es} 100044 \mathrm{n}$.

Heeren, N., Fishman, T., 2019. A database seed for a community-driven material intensity research platform. Sci. Data 6,1-10. https://doi.org/10.1038/s41597019-0021-X.

Heeren, N., Hellweg, S., 2018. Tracking construction material over space and time: prospective and geo-referenced modeling of building stocks and construction material flows. J. Ind. Ecol. 00, 1-15. https://doi.org/10.1111/jiec.12739.

Henry, A., Elambo, N., T.J.H.M., Fabrice, O., Blanche, M., 2014. Embodied energy and CO2 analyses of mud-brick and cement-block houses. AIMS Energy 2, 18-40. https://doi.org/10.3934/energy.2014.1.18.

Hong, L., Zhou, N., Feng, W., Khanna, N., Fridley, D., Zhao, Y., Sandholt, K., 2016. Building stock dynamics and its impacts on materials and energy demand in China. Energy Policy 94, 47-55. https://doi.org/10.1016/j.enpol.2016.03.024.

Hu, M., Pauliuk, S., Wang, T., Huppes, G., van der Voet, E., Müller, D.B., 2010. Iron and steel in Chinese residential buildings: a dynamic analysis. Resour. Conserv. Recycl. 54, 591-600. https://doi.org/10.1016/j.resconrec.2009.10.016.

Huang, T., Shi, F., Tanikawa, H., Fei, J., Han, J., 2013. Materials demand and environmental impact of buildings construction and demolition in China based on dynamic material flow analysis. Resour. Conserv. Recycl. 72, 91-101. https:// doi.org/10.1016/j.resconrec.2012.12.013.

Jeong, Y.-S., Lee, S.-E., Huh, J.-H., 2012. Estimation of CO 2 emission of apartment buildings due to major construction materials in the Republic of Korea. Energy Build. 49, 437-442. https://doi.org/10.1016/j.enbuild.2012.02.041.
Jia Wen, T., Chin Siong, H., Noor, Z.Z., 2015. Assessment of embodied energy and global warming potential of building construction using life cycle analysis approach: case studies of residential buildings in Iskandar Malaysia. Energy Build. 93, 295-302. https://doi.org/10.1016/j.enbuild.2014.12.002.

Johnstone, I., 2001. Energy and mass flows of housing: a model and example. Build. Environ. 36, 27-41. https://doi.org/10.1016/S0360-1323(99)00065-7.

KC, S., Lutz, W., 2017. The human core of the shared socioeconomic pathways: population scenarios by age, sex and level of education for all countries to 2100 Glob. Environ. Chang. 42, 181-192. https://doi.org/10.1016/ j.gloenvcha.2014.06.004.

Kleemann, F., Lederer, J., Rechberger, H., Fellner, J., 2016. GIS-based analysis of Vienna's material stock in buildings: GIS-based analysis of material stock in buildings. J. Ind. Ecol. 21, 368-380. https://doi.org/10.1111/jiec.12446.

Koutamanis, A., van Reijn, B., van Bueren, E., 2018. Urban mining and buildings: a review of possibilities and limitations. Resour. Conserv. Recycl. 138, 32-39. https://doi.org/10.1016/j.resconrec.2018.06.024.

Krausmann, F., Wiedenhofer, D., Lauk, C., Haas, W., Tanikawa, H., Fishman, T. Miatto, A., Schandl, H., Haberl, H., 2017. Global socioeconomic material stocks rise 23 -fold over the 20th century and require half of annual resource use. Proc. Natl. Acad. Sci. 114, 1880-1885. https://doi.org/10.1073/pnas.1613773114.

Kumar, V., Hewage, K., Sadiq, R., 2015. Life cycle assessment of residential buildings. A case study in Canada, engineering and technology. Int. J. Energy Environ. Eng. 9, 1017-1025.

Lee, S., Tae, S., Roh, S., Kim, T., 2015. Green template for life cycle assessment of buildings based on building information modeling: focus on embodied environmental impact. Sustainability 7, 16498-16512. https://doi.org/10.3390/ su71215830.

Lee, N., Tae, S., Gong, Y., Roh, S., 2017. Integrated building life-cycle assessment model to support South Korea's green building certification system (G-SEED) Renew. Sustain. Energy Rev. 76, 43-50. https://doi.org/10.1016/ j.rser.2017.03.038.

Li, D., Cui, P., Lu, Y., 2016. Development of an automated estimator of life-cycle carbon emissions for residential buildings: a case study in Nanjing, China. Habitat Int. 57, 154-163. https://doi.org/10.1016/j.habitatint.2016.07.003.

Mesta, C., Kahhat, R., Santa-Cruz, S., 2018. Geospatial characterization of material stock in the residential sector of a Latin-American city. J. Ind. Ecol. 00, 1-12. https://doi.org/10.1111/jiec.12723.

Miatto, A., Schandl, H., Forlin, L., Ronzani, F., Borin, P., Giordano, A., Tanikawa, H., 2019. A spatial analysis of material stock accumulation and demolition waste potential of buildings: a case study of Padua. Resour. Conserv. Recycl. 142, 245-256. https://doi.org/10.1016/j.resconrec.2018.12.011.

Mosteiro-Romero, M., Krogmann, U., Wallbaum, H., Ostermeyer, Y., Senick, J.S., Andrews, C.J., 2014. Relative importance of electricity sources and construction practices in residential buildings: a Swiss-US comparison of energy related lifecycle impacts. Energy Build. 68, 620-631. https://doi.org/10.1016/ j.enbuild.2013.09.046.

Müller, D.B., 2006. Stock dynamics for forecasting material flows-case study for housing in The Netherlands. Ecol. Econ. 59, 142-156. https://doi.org/10.1016 j.ecolecon.2005.09.025.

Nemry, F., Uihlein, A., 2008. Environmental Improvement Potentials of Residential Buildings. IMPRO-Building). https://doi.org/10.2791/38942.

Nemry, F., Uihlein, A., Colodel, C.M., Wetzel, C., Braune, A., Wittstock, B., Hasan, I., Kreißig, J., Gallon, N., Niemeier, S., Frech, Y., 2010. Options to reduce the environmental impacts of residential buildings in the European Union-Potential and costs. Energy Build. 42, 976-984. https://doi.org/10.1016/j.enbuild.2010.01.009.

OECD, 2013. Material Resources, Productivity and the Environment. www.oecdilibrary.org.

Olaya, Y., Vásquez, F., Müller, D.B., 2017. Dwelling stock dynamics for addressing housing deficit. Resour. Conserv. Recycl. 123, 187-199. https://doi.org/10.1016/ j.resconrec.2016.09.028.

Ortiz-Rodríguez, O., Castells, F., Sonnemann, G., 2010. Life cycle assessment of two dwellings: one in Spain, a developed country, and one in Colombia, a country under development. Sci. Total Environ. 408, 2435-2443. https://doi.org/ 10.1016/j.scitotenv.2010.02.021.

Oyarzo, J., Peuportier, B., 2014. Life cycle assessment model applied to housing in Chile. J. Clean. Prod. 69, 109-116. https://doi.org/10.1016/j.jclepro.2014.01.090.

O’Neill, B.C., Kriegler, E., Ebi, K.L., Kemp-Benedict, E., Riahi, K., Rothman, D.S., van Ruijven, B.J., van Vuuren, D.P., Birkmann, J., Kok, K., Levy, M., Solecki, W., 2017. The roads ahead: narratives for shared socioeconomic pathways describing world futures in the 21 st century. Glob. Environ. Chang. 42, 169-180. https:// doi.org/10.1016/j.gloenvcha.2015.01.004.

Pajchrowski, G., Noskowiak, A., Lewandowska, A., Strykowski, W., 2014. Wood as a building material in the light of environmental assessment of full life cycle of four buildings. Constr. Build. Mater. 52, 428-436. https://doi.org/10.1016/ j.conbuildmat.2013.11.066.

Pauliuk, S., Milford, R.L., Mu, D.B., Allwood, J.M., 2013. The steel scrap age, 47, 3448-3454. https://doi.org/10.1021/es303149z.

Pauliuk, S., Wang, T., Müller, D.B., 2013. Steel all over the world: estimating in-use stocks of iron for 200 countries. Resour. Conserv. Recycl. 71, 22-30. https:// doi.org/10.1016/j.resconrec.2012.11.008.

Pinky Devi, L., Palaniappan, S., 2014. A case study on life cycle energy use of residential building in Southern India. Energy Build. 80, 247-259. https://doi.org/ 10.1016/j.enbuild.2014.05.034.

Ramesh, T., Prakash, R., Shukla, K.K., 2012. Life cycle energy analysis of a residential building with different envelopes and climates in Indian context. Appl. Energy 
89, 193-202. https://doi.org/10.1016/j.apenergy.2011.05.054

Rauf, A., Crawford, R.H., 2015. Building service life and its effect on the life cycle embodied energy of buildings. Energy 79, 140-148. https://doi.org/10.1016/ j.energy.2014.10.093.

Residential Energy Consumption Survey (RECS) - Energy Information Administration, 2019. https://www.eia.gov/consumption/residential/index.php.

Reyna, J.L., Chester, M.V., 2015. The growth of urban building stock: unintended lock-in and embedded environmental effects. J. Ind. Ecol. 19, 524-537. https:// doi.org/10.1111/jiec.12211.

Reza, B., Sadiq, R., Hewage, K., 2014. Emergy-based life cycle assessment (Em-LCA) of multi-unit and single-family residential buildings in Canada. Int. J. Sustain. Built. Environ. 3, 207-224. https://doi.org/10.1016/j.ijsbe.2014.09.001.

Riahi, K., van Vuuren, D.P., Kriegler, E., Edmonds, J., O'Neill, B.C., Fujimori, S Bauer, N., Calvin, K., Dellink, R., Fricko, O., Lutz, W., Popp, A., Cuaresma, J.C., KC, S., Leimbach, M., Jiang, L., Kram, T., Rao, S., Emmerling, J., Ebi, K. Hasegawa, T., Havlik, P., Humpenöder, F., Da Silva, L.A., Smith, S., Stehfest, E. Bosetti, V., Eom, J., Gernaat, D., Masui, T., Rogelj, J., Strefler, J., Drouet, L., Krey, V. Luderer, G., Harmsen, M., Takahashi, K., Baumstark, L., Doelman, J.C., Kainuma, M., Klimont, Z., Marangoni, G., Lotze-Campen, H., Obersteiner, M. Tabeau, A., Tavoni, M., 2017. The Shared Socioeconomic Pathways and their energy, land use, and greenhouse gas emissions implications: an overview. Glob. Environ. Chang. 42, 153-168. https://doi.org/10.1016/ j.gloenvcha.2016.05.009.

Schebek, L., Schnitzer, B., Blesinger, D., Köhn, A., Miekley, B., Linke, H.J., Lohmann, A., Motzko, C., Seemann, A., 2017. Material stocks of the non-residential building sector: the case of the Rhine-Main area. Resour. Conserv. Recycl. 123, 24-36. https://doi.org/10.1016/j.resconrec.2016.06.001.

Sharma, A., Marwaha, B.M., 2015. A methodology for energy performance classification of residential building stock of Hamirpur. HBRC J. 13, 337-352. https:/ doi.org/10.1016/j.hbrcj.2015.11.003.

Shukla, A., Tiwari, G.N., Sodha, M.S., 2009. Embodied energy analysis of adobe house. Renew. Energy 34, 755-761. https://doi.org/10.1016 j.renene.2008.04.002.

Steger, S., Bleischwitz, R., 2011. Drivers for the use of materials across countries J. Clean. Prod. 19, 816-826. https://doi.org/10.1016/j.jclepro.2010.08.016.

Stehfest, E., van Vuuren, D., Kram, T., Bouwman, L., Alkemade, R., Bakkenes, M. WUR, H.B., Bouwman, A., den Elzen, M., Janse, J., Lucas, P., van Minnen, J., M. C. PIK, A, A.G.P., 2014. Integrated Assessment of Global Environmental Change with IMAGE 3, vol. 0

Stehfest, E., van Vuuren, D., Kram, T., Bouwma, L., 2014. Integrated Assessment of Global Environmental Change with IMAGE 3.0. PBL Netherlands Environmental Assessment Agency, The Hague, the Netherlands.

Stephan, A., 2013. Towards a comprehensive energy assessment of residential buildings. The University of Melbourne, Australia. www msd unimelb.edu.au.

Stephan, A., Athanassiadis, A., 2017. Quantifying and mapping embodied environmental requirements of urban building stocks. Build. Environ. 114, 187-202. https://doi.org/10.1016/j.buildenv.2016.11.043.

Stephan, A., Athanassiadis, A., 2018. Towards a more circular construction sector: estimating and spatialising current and future non-structural material replacement flows to maintain urban building stocks. Resour. Conserv. Recycl. 129, 248-262. https://doi.org/10.1016/j.resconrec.2017.09.022.

Stephan, A., Stephan, L., 2014. Reducing the total life cycle energy demand of recent residential buildings in Lebanon. Energy 74, 618-637. https://doi.org/10.1016/ j.energy.2014.07.028

Stephan, A., Crawford, R.H., De Myttenaere, K., 2012. Towards a comprehensive life cycle energy analysis framework for residential buildings. Energy Build. 55 592-600. https://doi.org/10.1016/j.enbuild.2012.09.008.

Su, X., Zhang, X., 2016. A detailed analysis of the embodied energy and carbon emissions of steel-construction residential buildings in China. Energy Build. 119, 323-330. https://doi.org/10.1016/j.enbuild.2016.03.070. Contents.

Suzuki, M., Oka, T., Okada, K., 1995. The estimation of energy consumption and CO2 emission due to housing construction in Japan. Energy Build. 22, 165-169. https://doi.org/10.1016/0378-7788(95)00914-J.

Tanikawa, H., Hashimoto, S., 2009. Urban stock over time: spatial material stock analysis using 4d-GIS. Build. Res. Inf. 37, 483-502. https://doi.org/10.1080/ 09613210903169394.

EStat Japan, 2015 population census, basic complete tabulation on population and households Japan. https://www.e-stat.go.jp/en/stat-search/files?page=1\& layout $=$ datalist $\&$ touke $=00200521 \&$ tstat $=000001080615 \&$ cycle $=0 \&$ tclass $1=$ 000001089055\&tclass $2=000001089056 \&$ stat infid $=000031473242,2015$.

UN-HABITAT, 2013. Global housing Strategy framework document, activities of the united Nations human settlelments programme. http://eprints.lancs.ac.uk/ 29226/, 1-15.

Urge-Vorsatz, D., Petrichenko, K., Antal, M., Staniec, M., Labelle, M., Ozden, E., Labzina, E., 2012. Best Practice Policies for Low Energy and Carbon Buildings: A Scenario Analysis. Research Report Prepared by the Center for Climate Change and Sustainable Policy (3CSEP) for the Global Buildings Performance Network May 2012.

Utama, A., Gheewala, S.H., 2008. Life cycle energy of single landed houses in Indonesia. Energy Build. 40, 1911-1916. https://doi.org/10.1016/ j.enbuild.2008.04.017. Contents.

Utama, A., Gheewala, S.H., 2009. Indonesian residential high rise buildings: a life cycle energy assessment. Energy Build. 41 https://oi.org/10.1016/ j.enbuild.2009.07.025, 2263-1268.

Van Beers, D., Graedel, T.E., 2003. The magnitude and spatial distribution of in-use copper stocks in Cape Town, South Africa, South African. J. Sci. 99, 61-69. https://hdl.handle.net/10520/EJC97582.

Van Vuuren, D.P., Den Elzen, M.G.J., Lucas, P.L., Eickhout, B., Strengers, B.J., Van Ruijven, B., Wonink, S., Van Houdt, R., 2007. Stabilizing greenhouse gas concentrations at low levels: an assessment of reduction strategies and costs. Clim. Change 81, 119-159. https://doi.org/10.1007/s10584-006-9172-9.

van Vuuren, D.P., Riahi, K., Calvin, K., Dellink, R., Emmerling, J., Fujimori, S., KC, S., Kriegler, E., O'Neill, B., 2017. The Shared Socio-economic Pathways: trajectories for human development and global environmental change. Glob. Environ. Chang. 42, 148-152. https://doi.org/10.1016/j.gloenvcha.2016.10.009.

Wang, H., Li, N., Chen, W., Shi, J., 2017. Analysis on building sector's energy consumption and mitigation potential under SSP2. Energy Procedia 142, 2435-2440. https://doi.org/10.1016/j.egypro.2017.12.179.

Yang, X., Hu, M., Wu, J., Zhao, B., 2018. Building-information-modeling enabled life cycle assessment, a case study on carbon footprint accounting for a residential building in China. J. Clean. Prod. 183, 729-743. https://doi.org/10.1016/ j.jclepro.2018.02.070.

Zhang, W., Tan, S., Lei, Y., Wang, S., 2014. Life cycle assessment of a single-family residential building in Canada: a case study. Build. Simul. 7, 429-438. https:// doi.org/10.1007/s12273-013-0159-y. 